\title{
Article
}

Arq Neuropsiquiatr 2010;68(1):72-75

\section{Epidemiological aspects in neuroschistosomiasis}

\author{
Claudio Henrique Fernandes Vidal' ${ }^{1}$ Fernando Viana Gurgel ${ }^{4}$, \\ Maria Lucia Brito Ferreira², Hildo Rocha Cirne de Azevedo-Filho ${ }^{1,3}$
}

\begin{abstract}
The urbanization process of schistosomiasis has been described in the literature. The present report shows and discusses some epidemiological aspects of neuroschistosomiasis that emphasizes this trend. Method: The study was done between July, 2005 and June, 2006, and consisted of spinal cord schistosomiasis carriers at the moment of diagnosis. These patients were evaluated whatever the origin and period of the year that they developed the symptoms. Results: A total of 13 patients were evaluated. Ten cases (76.92\%) came from the Metropolitan Region of Recife, while the other zones (Zona da Mata, Agreste e Sertão) contributed with just three cases (23.07\%). October, November and December (post rainy period) concentrated the majority of the cases (61.54\%). Conclusion: The high spatial and temporal concentration of cases in relation to a recent endemic area for Schistosomiasis suggests that the immunological status may be an important factor for installation of Sschistosomal myelitis.
\end{abstract}

Key words: epidemiology, schistosomiasis mansoni, neuroschistosomiasis, myelitis.

\section{Aspectos epidemiologicos na neuroesquistossomose}

\section{RESUMO}

O processo de urbanização da esquistossomose vem sendo descrito na literatura. O presente estudo apresenta e discute alguns aspectos epidemiológicos na neuroesquistossomose que confirmam essa tendência. Método: $O$ estudo foi realizado entre julho de 2005 e junho de 2006, sendo composto por portadores de mielite esquistossomótica no momento do diagnóstico. Os pacientes foram avaliados quanto à procedência e ao período do ano que desenvolveram a doença. Resultados: No total foram 13 pacientes avaliados, sendo 10 casos (76,92\%) provenientes da Região Metropolitana do Recife, enquanto as demais regiões (Zona da Mata, Agreste e Sertão) contribuíram com apenas um caso cada. Os meses de outubro, novembro e dezembro concentraram a maioria dos pacientes $(61,54 \%)$. Conclusão: A alta concentração espacial e temporal de casos em relação a uma área endêmica recente para esquistossomose sugere que a participação de fatores imunológicos possa ser importante para o desenvolvimento de sua forma medular. Palavras-chave: epidemiologia, esquistossomose mansoni, neuroesquistossomose, mielite.

Schistosomiasis is one of the older and more diffused parasitic diseases of the world, and nowadays represents a serious public health problem. It is endemic in more than 74 countries, and is responsible for the majority of the cases of portal hypertension among the young population. Around the world, it is believed that there are 200 million people infected by the specimens mansoni, haematobium, japonicum, intercalatum or mekong $g^{1,2}$. Originally from the African continent, Schistosoma mansoni $(S M)$ was brought to Brazil during the slave period, and found favorable weather conditions and a large number of hosts for its proliferation. Currently, bad sanitary
Rua Francisco da Cunha 206 51020-041 Recife PE - Brasil

E-mail: vidal-claudio@ig.com.br

Received 31 May 2009

Received in final form 8 September 2009 Accepted 18 September 2009
Centro de Ciências da Saúde da Universidade Federal de Pernambuco (UFPE), Recife PE, Brazil: 'Departamento de Pós-graduação em Neuropsiquiatria e Ciências Comportamentais; ${ }^{2}$ Chefe do Departamento de Neurologia; ${ }^{3}$ Chefe do Departamento de Neurocirurgia; ${ }^{4}$ Radiologista. 
conditions in Brazil perpetuate the endemic status of this grave parasitic disease ${ }^{2}$. The clinical temporal forms of the disease are: acute (toxemic and non-toxemic), latent and chronic ${ }^{2,3}$. The latter is divided in light forms (intestinal and hepatointestinal) and grave forms (hepatosplenic, pulmonary and glomerular) ${ }^{2,3}$. In the acute stage, the nontoxemic form course is without significant symptoms or signs. The toxemic form course with fever between the $15^{\text {th }}$ and $45^{\text {th }}$ day after the infestation, and this represents hyper-sensibility to the antigens and eggs of the worm. This reaction is mild among individuals living in an endemic area. The latent period is a transition between the acute and chronic phases $\left(90^{\text {th }}\right.$ to $120^{\text {th }}$ day after the infestation $)^{2,3}$. In the chronic stage, the intestinal form is the most common and is usually somewhat symptomatic.

The nervous system (NS) is the most common ectopic foci of Schistosoma mansoni infection and its involvement may result in a broad range of complications. Post-mortem studies have showed that 20 to $30 \%$ of the patients with schistosomiasis have some NS lesion, being, thus, the number of asymptomatic individuals near the triple of those who actually develop neurological symptoms ${ }^{4}$. In neuroschistosomiasis, the spinal cord is the most common place of the disease ${ }^{5}$. The exact frequency of myelopathy in these patients has never been properly studied, in part because of the wide variations in clinical expres$\operatorname{sion}^{6}$. Nowadays, neuroschistosomiasis is considered the third most common cause of myelopathy, after traumatic and tumor involvements ${ }^{7,8}$. The presence and clinical significance neurological lesions depend on the combination of the presence of eggs and the immune response of the host. In the majority of cases, there occurs a delayed immune response type four or granulomatous, and is higher in the beginning of schistosomiasis, while in chronic forms it becomes localized and lighter (immunological modulation phenomenon) $)^{9,10}$.

The present report brings some concepts about epidemiological aspects in schistosomal myelitis illness that disrupts the classical view that linked this disease to very prevalent zones for schistosomiasis. The authors try to register some causal association between these epidemiological concepts and the immunological status of the patients before the spinal cord involvement. This information can contribute to a better physiopathogenic understanding of this intriguing condition.

\section{METHOD}

The study protocol was approved by the institutional review board of the participating center (Restauração Hospital) and patients gave written consent for data analysis.

It was a descriptive evaluation (series of cases), from a hospital base, where the sample consisted of Schistosomiasis mansoni carriers at the moment of the diagnosis of myelitis. The patients were interned in the neurological infirmary, during July, 2005 and June, 2006.

The authors used as inclusion criteria, the recommendations for diagnosis from the Centers for Disease Control $(\mathrm{CDC})^{11}$ : dysfunction of thoracic or lumbosacral spinal cord; parasitological confirmation of the infection by $S M$ and exclusion of other causes for transversal myelitis.

Pernambuco is a State in the Northeast of Brazil and has four great areas from the coast to the interior of the State: the Metropolitan Region of Recife (Great Recife), Forest Zone (Zona da Mata), Agreste and the Hinterland (Sertão). For the study purpose, this division was used. The period of time of the study was divided by each three months, and included: $1^{\text {st }}$ trimester (July, August and September); $2^{\text {nd }}$ trimester (October, November and December); $3^{\text {rd }}$ (January, February and March); $4^{\text {th }}$ (April, May and June). Then, the patients were evaluated whatever the origin and period of the year that they developed the disease.

The results were expressed by means, absolute and relatives values. For age description, the minimal and maximal values were considered too.

\section{RESULTS}

A total of 13 patients were evaluated during the period of study. The clinical data are show in Table.

\section{DISCUSSION}

The distribution, whatever the gender, was very similar (53.84\% of males and $46.15 \%$ of females), and diverges from the literature, that refers to men at a greater risk for acquiring this condition. This occurs because of social and economic factors like recreational activities and

Table. Distribution of the individuals in relation to gender, age, origin and period of year that the disease occurred.

\begin{tabular}{lcc}
\hline Clinical data & $\mathrm{n}$ & $\%$ \\
\hline Gender & 7 & 53.84 \\
$\quad$ Male & 6 & 46.15 \\
Female & & \\
Age & & \\
Mean: 27.31 years old & & \\
Minimal: 15 years old & & \\
Maximal: 47 years old & & \\
Origin & 10 & 76.92 \\
Great Recife & 1 & 7.69 \\
Zona da Mata & 1 & 7.69 \\
Agreste & 1 & 7.69 \\
Sertão (Hinterland) & & \\
Period of study & & 15.54 \\
$1^{\text {st }}$ trimester & 2 & 61.54 \\
$2^{\text {nd }}$ trimester & 8 & 15.38 \\
$3^{\text {rd }}$ trimester & 2 & 7.69 \\
$4^{\text {th }}$ trimester & 1 & \\
\hline
\end{tabular}


heavy work, and consequently a higher frequency of physical efforts, among men, that cause higher levels of abdominal inner pressure ${ }^{6,12,13}$.

The mean age among the patients was 27.31 years (with a minimal of 15 and a maximum of 47 years). These results are in accordance with other reports ${ }^{5,14}$, and reflect the most prevalent age for schistosomiasis (between 10 and 40 years of age $)^{3}$. Young individuals usually are more exposed to contaminated waters, moreover they usually are involved in more physical activities too, and therefore are more susceptible to higher abdominal pressure.

In the sample of the study, the majority of the cases (76.92\%) came from the Metropolitan Region of Recife. It has been considered a recent endemic area for schistosomiasis, and differs from the classical distribution of this disease in Pernambuco State, where the Zona da Mata (Forest Zone), and its strict correlation with sugar-cane culture, has been the most prevalent area ${ }^{15}$. Analyzing the Asano ${ }^{16}$ report in relation to origin, she found that $48.27 \%$ of the patients with schistosomal myelitis came from the Metropolitan Region of Recife, and just 24.13\% were from the Forest Zone (Zona da Mata). This information corroborates the urbanization process of schistosomiasis that has been described in the literature, occurring because of the disorganized growth of cities and migratory movements from the field, and almost always reflects the precariousness of the local sanitary-hygienic conditions ${ }^{15,17}$. The two other individuals came from two small endemic areas for schistosomiasis (the Agreste and the Sertão).

The immune status before, during and after the infection, is maybe the most important factor in the determination and evolution of the clinical forms of Schistosomiasis mansoni ${ }^{3}$. The NS lesions are probably conditioned by this immunological predisposition, and are more accentuated among individuals that have suffered recent exposition to the parasite, especially those that did not come from endemic area ${ }^{2,3}$. Although the present report doesn't intend to be an epidemiological inquiry, the analyses about the origin of the patients suggest that living in recent areas for the disease or low index of previous exposition to the parasite, can contribute to the development of myelitis by Schistosoma.

A natural critique to the previous assertion is the fact that the sample was of convenience, and the place where study was done is in the area of highest prevalence found in this analysis. The small representation of the other regions can reflect a greater difficulty of the patients from the inland of the State in accessing public health services or the hospital itself, where the study was developed. Definitely a bias of selection could occur. On the other hand, the precariousness of the health network of Pernambuco State, especially for neurological disease, makes the sample from Restauração Hospital (one of the few tertia- ry centers) representative enough of the whole State. In view of this fragile information, the same has to be interpreted with caution.

Another interesting observation was that the cases were concentrated (61.54\%) in the last trimester of 2005 (second trimester of the study), and all these patients came from the Metropolitan Region of Recife. This fact coincides with Barbosa et al. report ${ }^{15}$ that found a greater population of Biomphalaria and a higher infection rate among these vectors in the post rainy period (October, November and December) during analyses of cases of urban schistosomiasis at Itamaracá Island. In this study the existence of perennial reservoirs of the slug was described which have been infected by construction workers that migrated from the rural regions. These reservoirs spill over during the rainy period (May to August), and then secondary reservoirs are formed. These maintain a sufficient amount of water during the post rainy period, and the slugs can reproduce in a great abundance and disseminate the disease.

In conclusion, the high spatial and temporal concentration of cases in relation to a recent endemic area for schistosomiasis (Metropolitan Region of Recife) can permit one to conjecture that a recent first time exposure of these patients with contaminated waters could make them more susceptible to develop a favorable immunological environment for installation of schistosomal myelitis. This differs from individuals that live in classical endemic zones for schistosomiasis, which the contamination embraces, sometimes, for several generations of the same family. The exposure can occur, inclusively, in an intrauterine environment (by passage of parasitic antigens or antibodies) $)^{3}$ or by gradual exposure to the parasite from an early age. Another possibility is that the immunogenic capacity of different samples of Schistosoma mansoni is distinct in its capacity for tissue damage ${ }^{3}$. Maybe in the Metropolitan Region of Recife exists samples with a higher capacity for damage the NS.

\section{REFERENCES}

1. Doumenge JP. Atlas de la répartition mondiale des schistosomiasis. Genève: OMS/WHO; 1987.

2. Coutinho AD, Domingues ALC. Esquistossomose mansoni. In: Dani R, Castro LP (Eds). Gastroenterologia clínica. Rio de Janeiro: Guanabara Koogan, 1993:1697-1728.

3. Raso P. Esquistossomose Mansônica. In: Filho GB (Ed). Bogliolo Patologia. Rio de Janeiro: Guanabara Koogan, 2000:1186-1207.

4. Andrade AN. Neuroesquistossomose. Arq Neuropsiquiatr 1986;44:275-279.

5. Peregrino AJP, Oliveira SP, Porto CA, et al. Meningomielorradiculite por Shistosoma mansoni - Protocolo de investigação e registro de 21 casos. Arq Neuropsiquiatr 1988;46:49-60.

6. Santos EC, Campos GB, Diniz AC, Leal JC, Rocha MOC. Perfil clínico e critérios diagnósticos da mielorradiculopatia esquistossomótica. Arq Neuropsiquiatr 2001;59:772-777.

7. Spina-França A, Salum PNB, Limongi JCP, Berger A, Losso ER. Mielopatias: aspectos diagnósticos. Arq Neuropsiquiatr 1980;38:360-366. 
8. Brito JCF, Nóbrega PV. Mielopatias: considerações clínicas e aspectos etiológicos. Arq Neuropsiquiatr 2003;61: 816-821.

9. Pitella JEH. The relation between involment of the central nervous system in schistosomiasis mansoni and forms of the parasitosis. A review. J Trop Med Hyg 1991;94:15-21.

10. Ferrari TCA, Moreira PRR, Cunha AS. Spinal-cord involvement in the hepato-splenic form of Schistosoma mansoni infection. Ann Trop Med Parasitol 2001;95:633-635.

11. Centers for Disease Control and Prevention: acute schistosomiasis with transverse myelitis in American students returning from Kenya. Morb Mortal Wkly Rep 1984;33:446-447.

12. Peregrino AJP, Puglia PMK, Nóbrega JPS, Livramento JA, Marques-Dias MJ, Scaff M. Esquistossomose medular: análise de 80 casos. Arq Neuropsiquiatr 2002;60:603-608
13. Galvão ACR. Milelopatias esquistossomóticas; aspectos clínicos e laboratoriais. Dissertação de Mestrado. Universidade de São Paulo. São Paulo, 1983.

14. Santos EC. Perfil diagnóstico da mielorradiculopatia esquistossomótica em três hospitais de Belo Horizonte: estudo retrospectivo - 1972 a 1992. Dissertação Mestrado. Faculdade de Medicina da UFMG. Belo Horizonte, 1994.

15. Barbosa CS, Pieri OS, Silva CB, Barbosa FS. Ecoepidemiologia da esquistossomose urbana na ilha de Itamaracá, Estado de Pernambuco. Rev Saúde Pública 2000;34: 337-341.

16. Asano NMJ. Neuroesquistossomose: aspectos clínicos, laboratoriais e de imunodiagnóstico. Dissertação de Mestrado. Universidade Federal de Pernambuco. Recife, 1992.

17. Lima VLC. A esquistossomose urbana e a heterogeneidade social e epidemiológica da população do município de Campinas, São Paulo, Brasil. Cad Saúde Pública 1995;11:45-56. 